\title{
Zestalanie zużytych płuczek wiertniczych - próba półprzemysłowa
}

\begin{abstract}
W artykule przedstawiono wyniki badań laboratoryjnych zestalania płuczek bentonitowych i beziłowych polimerowych pod kątem dobru rodzaju i optymalnej ilości środka wiążącego oraz badania otrzymanego zestalonego półproduktu. Przy zestalaniu płuczki ważny jest dobór środków wiążących, których zadaniem jest takie przekształcenie suspensji płuczki wiertniczej w ciało stałe o odpowiedniej wytrzymałości mechanicznej, aby w jak największym stopniu ograniczyć wymywanie się z niego substancji niebezpiecznych występujących w postaci związków rozpuszczalnych. W wyniku tych badań wytypowano zestaw środków stanowiących kompozycję na bazie cementu portlandzkiego CEM I 32,5 lub spoiwa hydrauliczne-

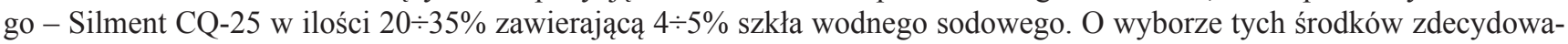
ły ich właściwości chemiczne i wpływ na właściwości mechaniczne ciała stałego powstałego po zestaleniu płuczki otworowej. W celu weryfikacji opracowanej technologii zestalania zużytych płuczek wiertniczych przeprowadzono próbę w skali półprzemysłowej. Zestalony półprodukt poddano badaniom pod kątem wytrzymałości na ściskanie - po 7 dniach wytrzymałość wynosiła 0,9 MPa, a po 14 dniach - 1,9 MPa. Przeprowadzone badania wymywalności substancji szkodliwych w odcieku z półproduktu wykazały następujące wartości oznaczeń: stałe związki rozpuszczone (TDS) - $58424 \mathrm{mg} / \mathrm{kg}$ s.m., chlorki Cl- - 21300 mg/kg s.m., siarczany - 1984 mg/kg s.m., ogólny węgiel organiczny (DOC) - 3200 mg O²/kg s.m., zawartość metali ciężkich - na niskim poziomie. Spośród wykonanych oznaczeń jedynie zawartość węgla organicznego (DOC) przekroczyła graniczne wartości wymywania (Dz.U. z 2015 r., poz. 1277, załącznik nr 5), co mogło być spowodowane obecnością polimerów organicznych zawartych w składach zestalonych płuczek oraz zanieczyszczających je substancji ropopochodnych. Ponadto wykonano badania toksykologiczne odcieku z zestalonego półproduktu z wykorzystaniem wytypowanych testów toksykologicznych. Toksyczność wyrażona w jednostkach toksyczności (TU) w wytypowanych do badań testach wynosiła: Microtox - 4,3; Daphtoxkit (48 h) - 9,9; Spirodela - 9,5. Odciek z półproduktu można zaliczyć do niskotoksycznych (II klasa toksyczności, TU < 10). Prezentowana technologia została objęta ochroną patentową nr P.418959 pt.: Sposób zestalania zużytych wodnodyspersyjnych płuczek wiertniczych typu bentonitowego i polimerowego.
\end{abstract}

Słowa kluczowe: zużyte płuczki wiertnicze, zestalanie, środki wiążące, testy toksykologiczne.

\section{Solidification of used drilling muds - semi-industrial test}

The article presents results of laboratory tests of solidification of bentonite and non-clay polymeric muds to select a type and an optimum amount of a bonding agent and to examine the obtained solidified semi-finished product. When solidifying the fluid, it is important to select binding agents, the task of which is to convert the suspension of the drilling fluid into a solid body of sufficient mechanical strength in order to minimize the leaching of hazardous substances in the form of soluble compounds. As a result of these tests, a set of agents constituting a composition based on Portland cement CEM I 32.5 or hydraulic binder - CQ-25 Silment in the amount of $20 \div 35 \%$ containing $4 \div 5 \%$ sodium water glass was selected. The choice of these agents was determined by their chemical properties and their effect on the mechanical properties of the solid produced after the solidification of the borehole fluid. In order to verify the developed technology of solidification of used drilling fluids, a semi-industrial test was carried out. The semi-product of solidification was tested for compressive strength - after 7 days it was $0.9 \mathrm{MPa}$, whereas after 14 days - 1.9 MPa. The test of leaching of harmful substances in the leachate from the semifinished product, showed the following values of determinations: solid dissolved compounds (TDS) - $58424 \mathrm{mg} / \mathrm{kg} \mathrm{d}$. m., Cl-chlorides - $21300 \mathrm{mg} / \mathrm{kg} \mathrm{d}$. m., sulphates - $1984 \mathrm{mg} / \mathrm{kg} \mathrm{d}$. m., total organic carbon (DOC) - $3200 \mathrm{mg} \mathrm{O} / 2 \mathrm{~kg} \mathrm{~d}$. m., heavy metal content, which was at a low level. Of the performed determinations, only organic carbon content (DOC) exceeded the leaching limit values (Journal of Laws of 2015, item 1277, Appendix no. 5), which may have been caused by the presence of organic polymers contained in solidified fluids and petroleum substances contaminating them. In addition, toxicological studies of leachate from the solidified semi-finished product were performed using selected toxicological tests. The toxicity expressed in TU units of the tests selected for the research was as follows: Microtox - 4.3; Daphtoxkit (48 h) - 9.9; Spirodela - 9.5. 
Leachate from the semi-finished product may be classified as low toxic (toxicity class II TU $<10$ ). The presented technology has been granted patent protection No. P. 418959 under the title The method of solidification of used water dispersion bentonite and polymeric drilling fluids, which was awarded with a gold medal at the international exhibition of inventions in Geneva.

Key words: used drilling muds, solidification, bonding agents, toxicological tests.

\section{Wprowadzenie}

Podczas prowadzenia prac poszukiwawczych wytwarzane są duże ilości odpadów, które występują w postaci zużytej płuczki wiertniczej i wynoszonego przez nią urobku. Pod-

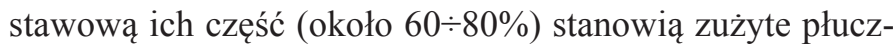
ki wiertnicze jako odpady płynne, natomiast pozostała ilość to odpady stałe w postaci zwiercin zanieczyszczonych płuczką oraz uwodnionych osadów usuwanych ze ściany otworu $\mathrm{w}$ trakcie jego rurowania. Wytworzone odpady mogą charakteryzować się podwyższoną szkodliwością dla środowiska ze względu na wysoką zawartość jonów chlorkowych (w przypadku płuczek o wysokim stopniu zasolenia) i siarczanowych, metali ciężkich, substancji organicznych mierzonych wskaźnikiem ChZT $_{\mathrm{Cr}}$ itp. $[8,9,10]$.

W związku z tym podjęte zostały próby minimalizacji ilości odpadów wiertniczych, a w szczególności odpadów płynnych, oraz obniżenia stopnia ich szkodliwości w procesie wiązania zużytej płuczki wiertniczej przy użyciu odpowiednio dobranych środków wiążących $[8,10]$. Na podstawie szeregu przeprowadzonych w INiG - PIB laboratoryjnych badań zużytych pluczek wiertniczych, różniących się składem, właściwościami reologicznymi, gęstością i zawartością skażeń chemicznych, opracowano kompozycję środka zestalającego oraz technologię ich zestalania wraz z metodyką oceny właściwości mechanicznych, chemicznych i toksykologicznych pozyskanego półproduktu.

Wyniki badań wykazały, że odpowiednio dozując zestaw (kompozycję) środków wiążących, takich jak szkło wodne-spoiwa hydrauliczne (cement portlandzki - CEM I 32,5 lub spoiwo hydrauliczno-pucolanowe zawierające dużą ilość aktywnej krzemionki - Silment CQ-25), można przeprowadzić proces zestalania koloidalnej suspensji takich płuczek w ciało stałe. Ilości środków wiążących wchodzących w skład kompozycji zależały od rodzaju zestalanej płuczki i stopnia jej uwodnienia. Otrzymane ciało stałe (półprodukt) poddawano badaniom mechanicznym celem określenia wytrzymałości na ściskanie oraz dokonano jego oceny ekologicznej, obejmującej badania wymywalności niebezpiecznych substancji i badania toksyczności odcieku, dzięki czemu można określić wpływ zestalonego półproduktu na środowisko [10, 12].

\section{Omówienie wyników badań prowadzonych w celu opracowania technologii zestalania zużytych płuczek wiertniczych}

Zestalanie płuczki wiertniczej jest technologicznie trudniejszym procesem niż zestalanie urobku ze względu na jej płynną postać zagęszczoną zdyspergowanymi polimerami i cząstkami ilastymi pochodzącymi z przewiercanych warstw oraz zawierającą rozpuszczone związki chemiczne, które stosowane są do regulowania i obróbki jej parametrów technologicznych, przy czym mogą również reprezentować skażenia występujące w profilu geologicznym otworu. Niekorzystne działanie na proces zestalania płuczki niektórych jej składników, a w szczególności polimerów organicznych i skażeń chemicznych w postaci np. jonów $\mathrm{Ca}^{2+} \mathrm{i} \mathrm{Mg}^{2+}$, potwierdziły liczne badania różnych rodzajów płuczek otworowych pochodzących z głębokości od około $300 \mathrm{~m}$ do ponad $4000 \mathrm{~m}$ oraz sporządzonych w warunkach laboratoryjnych koloidalnych zawiesin polimerów stosowanych do regulowania ich właściwości technologicznych i kontrolowania zjawisk fizykochemicznych w układzie płuczka wiertnicza-skała [7, 11]. Dlatego bardzo ważny jest dobór środków wiążących, których zadaniem jest takie przekształcenie suspensji płuczki wiertniczej w ciało stałe o odpowiedniej wytrzymałości mechanicz- nej, aby w jak największym stopniu ograniczyć wymywanie z niego substancji niebezpiecznych występujących w postaci związków rozpuszczalnych.

Zestalanie zużytych, odpadowych płuczek otworowych prowadzono w dwóch etapach dla rozpoznania możliwości wiązania płuczki w całość jako fazy płynnej przy użyciu wytypowanych środków wiążących i stabilizujących, takich jak: cement, spoiwo hydrauliczno-pucolanowe zawierające dużą ilość aktywnej krzemionki - Silment CQ-25, spoiwo na bazie klinkieru portlandzkiego z dodatkami mineralnymi - Gruntar, szkło wodne sodowe oraz tlenek wapnia $[6,12,13]$. Celem badań etapu pierwszego był wstępny dobór rodzaju środków wiążących, określany na podstawie zmiany konsystencji płuczki otworowej przy zadawanych kolejnych dawkach danego środka, wzrostu wartości parametrów reologicznych, aż do momentu uzyskania niemierzalnych ich wartości, oraz obserwacji objawów występowania odstoju wody w czasie wiązania. Natomiast podstawowym celem badań etapu drugiego był dobór optymalnej ilości wybranych środków wiążących wprowadzanych do suspensji płuczki w odpowiedniej kolejności, 
pod kątem ich wpływu na czas początku i końca wiązania, wytrzymałość na ściskanie zestalonej próbki płuczki oraz wymywalność z niej substancji niebezpiecznych.

W wyniku tych badań wytypowano zestaw środków stanowiących kompozycję na bazie cementu portlandzkiego CEM I 32,5 lub spoiwa hydraulicznego - Silment CQ-25 w ilości $20 \div 35 \%$, która zawierała $4 \div 5 \%$ szkła wodnego sodowego na $1 \mathrm{~m}^{3}$ płuczki. O wyborze tych środków zdecydowały ich właściwości chemiczne i wpływ na właściwości mechaniczne ciała stałego powstałego po zestaleniu płuczki otworowej. Zastosowanie wybranych środków wymagało opracowania technologii zestalania, która polegała na wprowadzeniu do płuczki w pierwszej kolejności zadanej ilości szkła wodnego, a następnie, po około 30 min mieszania, wytypowanych materiałów wiążących. Zżelowaną, jednorodną masę mieszaniny przenoszono do pojemników, gdzie przez okres od 7 do 14 dni (a nawet $28 \mathrm{dni}$ ) przechowywano ją w temperaturze otoczenia, prowadząc pomiary czasu wiązania i wytrzymałości na ściskanie oraz obserwacje próbki w czasie twardnienia.

W opracowanej kompozycji środka do zestalania odpadowych, zużytych płuczek wiertniczych szkło wodne pełniło rolę aktywatora wiązania, natomiast cement CEM I 32,5 i Silment CQ-25 stosowano zamiennie jako materiały wiążące w celu porównania i określenia efektywności ich działania, głównie ze względu na wytrzymałość na ściskanie otrzymanego materiału stałego i wymywalność z niego substancji niebezpiecznych. Zwiększanie zawartości materiałów wiążących miało wpływ na podwyższanie wytrzymałości na ściskanie otrzymywanego półproduktu. Dodatki cementu CEM I 32,5 i Silmentu CQ-25 oddziaływały także na czas wiązania próbek płuczki, jednak głównym czynnikiem wpływającym na czas zestalenia płuczki wiertniczej była ilość szkła wodnego oraz rodzaj płuczki. Czas początku i końca wiązania oznaczano za pomocą aparatu Vicata, natomiast wytrzymałość na ściskanie przy użyciu maszyny wytrzymałościowej. Pomiary te wykonywano zgodnie z procedurami obowiązującymi dla wiążących i stwardniałych zaczynów uszczelniających.
Jak wykazały badania, każda płuczka otworowa wymagała indywidualnego doboru ilości środków wiążących i stabilizujących dla uzyskania jednorodnej masy oraz optymalnych parametrów wytrzymałościowych powstałego z niej półproduktu. Miały na to wpływ zarówno rodzaj płuczki, jak i stopień jej zasolenia oraz skażenia związkami chemicznymi, a także zawartość w składzie danej płuczki różnego rodzaju polimerów.

Przeprowadzone badania wykazały, że płuczki bentonitowe łatwiej ulegają zestalaniu niż płuczki polimerowe. Wiązanie próbki płuczki bentonitowej zachodziło maksymalnie po około dwóch dniach, natomiast proces wiązania płuczek polimerowych trwał do $6 \div 8$ dni. Początek czasu wiązania płuczki bentonitowej zestalonej przy zastosowaniu $4 \div 5 \%$ szkła wodnego i $20 \div 35 \%$ materiału wiążącego oznaczano po $28 \mathrm{~h}$, a koniec po maksymalnie $55 \mathrm{~h}$. Podczas zestalania płuczek polimerowych, przy zastosowaniu tych samych ilości i rodzajów środków zestalających, zaobserwowano, że ich twardnienie zachodziło najszybciej w warstwie powierzchniowej, natomiast środek próbki pozostawał niejednokrotnie w postaci wilgotnej ziemi. Wymagało to przyjęcia dłuższego czasu wiązania celem właściwego określenia parametrów wytrzymałościowych pozyskiwanego półproduktu.

Na rysunkach 1 i 2 przedstawiono proces wiązania próbki płuczki bentonitowej przy użyciu kompozycji na bazie cementu portlandzkiego CEM I 32,5 w ilości $20 \div 30 \%$ oraz spoiwa hydraulicznego - Silment CQ-25 w ilości 20 $\div 35 \%$ z dodatkiem 5\% szkła sodowego. Wytrzymałości na ściskanie próbek zawierających cement portlandzki po 14 dniach wynosiły od około 0,5 MPa do 1,17 MPa, natomiast zawierających Silment CQ-25 - od około 0,7 MPa do 1,0 MPa.

Płuczki potasowo-polimerowe charakteryzowały się wysokim stopniem zasolenia i zawierały w składach głównie środki celulozowe typu PAC o różnej lepkości w połączeniu z CMC LV, żywicę ksantanową oraz PHPA i poliglikol. Wartości wytrzymałości półproduktu z zastosowanej płuczki zawierającego $4 \%$ i $5 \%$ szkła sodowego oraz $20 \div 35 \%$ materiału wiążącego mieściły się w zakresie $0,65 \mathrm{MPa}$ do 1,2 MPa.

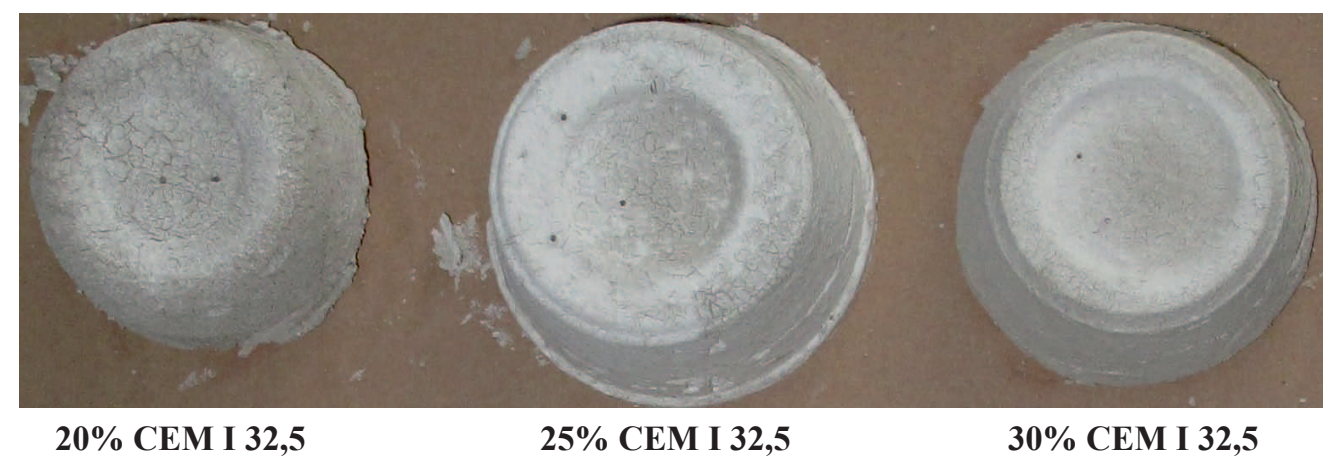

Rys. 1. Płuczka bentonitowa po zestaleniu przy użyciu 5\% szkła sodowego oraz cementu portlandzkiego CEM I 32,5 w ilości 20 $\div 30 \%$ 


\section{NAFTA-GAZ}

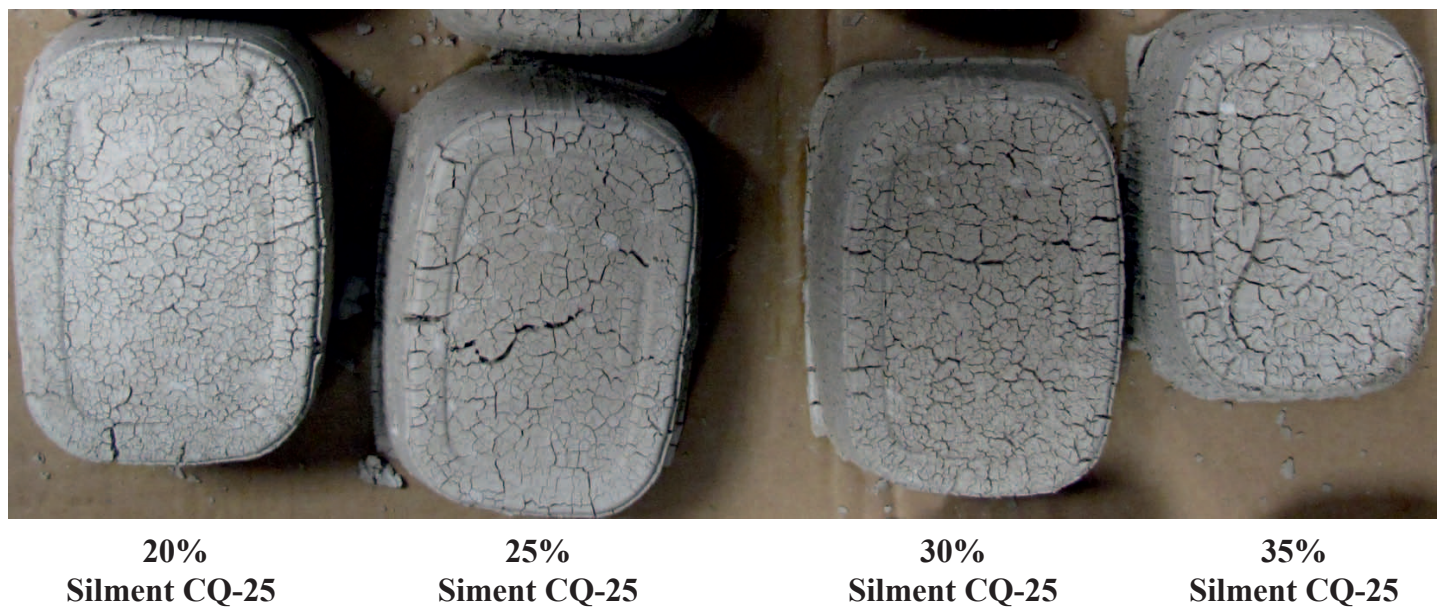

Rys. 2. Płuczka bentonitowa po zestaleniu przy użyciu 5\% szkła sodowego oraz Silmentu CQ-25 w ilości $20 \div 35 \%$

Ze względu na prawie pełne zasolenie tych płuczek - podczas ich twardnienia na powierzchni próbek półproduktu zachodziła krystalizacja soli (rysunki 3, 4), która w większym stopniu występowała w próbkach zestalonych cementem.

Opracowana w INiG - PIB technologia zestalania koloidalnych zawiesin odpadowych płuczek wiertniczych ob- jęta zgłoszeniem patentowym z 29 września 2016 r., numer P.418959, może być z powodzeniem stosowana w warunkach przemysłowych jako jedna z metod odzysku i unieszkodliwiania odpadów wiertniczych, co potwierdziły wyniki próby półprzemysłowej przeprowadzonej na terenie Instytutu w Oddziale Krosno.

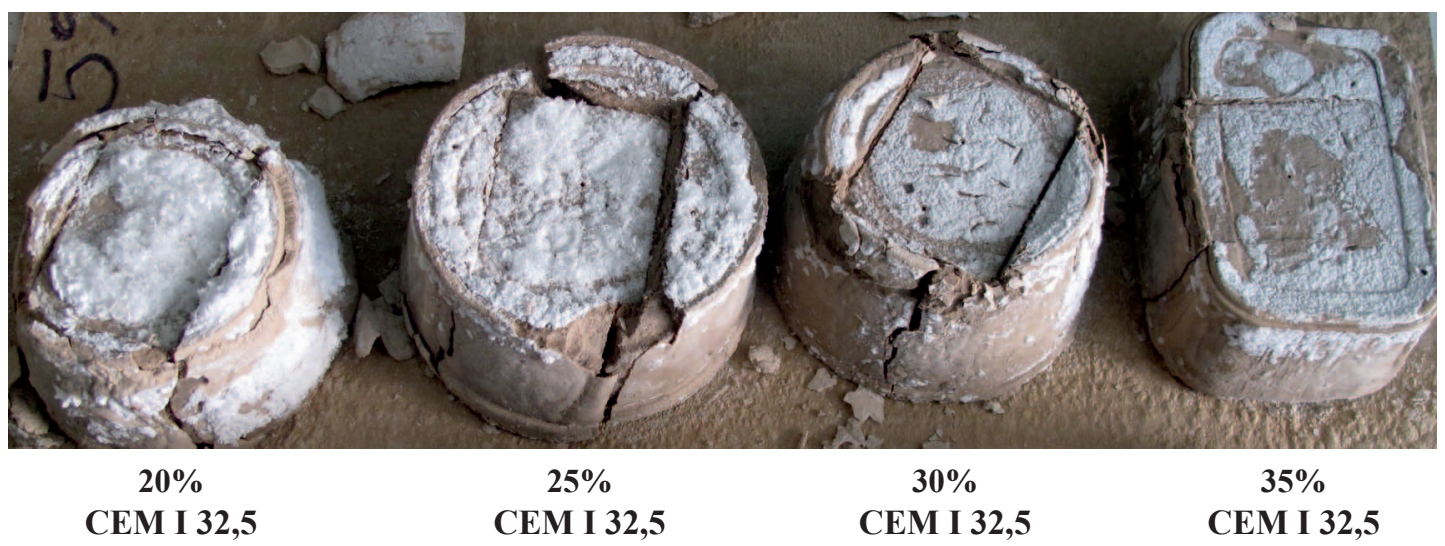

Rys. 3. Płuczka zasolona potasowo-polimerowa po zestaleniu przy użyciu 5\% szkła sodowego oraz cementu portlandzkiego CEM I 32,5 w ilości 20 $\div 35 \%$

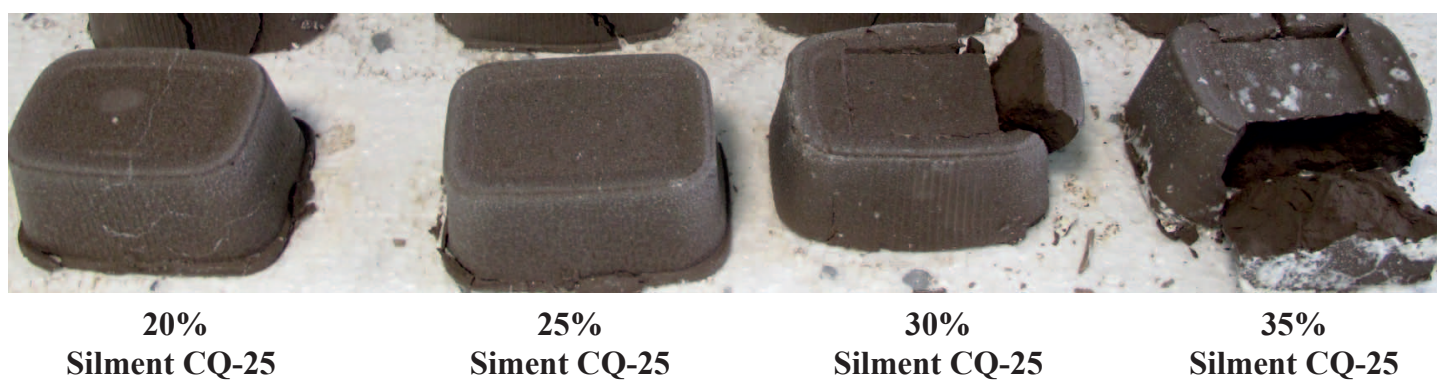

Rys. 4. Płuczka zasolona potasowo-polimerowa po zestaleniu przy użyciu 5\% szkła sodowego oraz Silmentu CQ-25 w ilości $20 \div 35 \%$ 


\section{Omówienie wyników próby półprzemysłowej zestalania zużytej płuczki wiertniczej}

W celu weryfikacji w skali półprzemysłowej skuteczności zestalania płuczek według technologii opracowanej w INiG - PIB zgromadzono około $0,75 \mathrm{~m}^{3}$ mieszaniny płuczek bentonitowych i polimerowych o różnym zasoleniu (rysunki 5, 6).

Przed przystąpieniem do wykonania próby półprzemysłowej mieszaninę płuczek otworowych (tablica 1) poddano zestaleniu w warunkach laboratoryjnych, zgodnie z zaleceniami zawartymi w opracowanej technologii, przy użyciu kompozycji na osnowie $30 \%$ i $35 \%$ cementu CEM I 32,5 z dodatkiem 4\% i 5\% szkła sodowego.

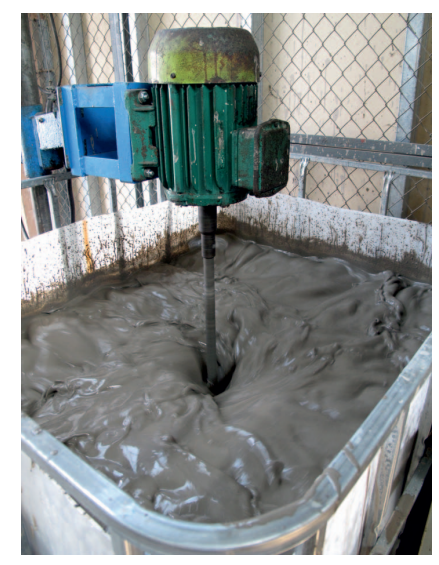

Rys. 5. Mieszanina płuczek przygotowywana do wykonania próby

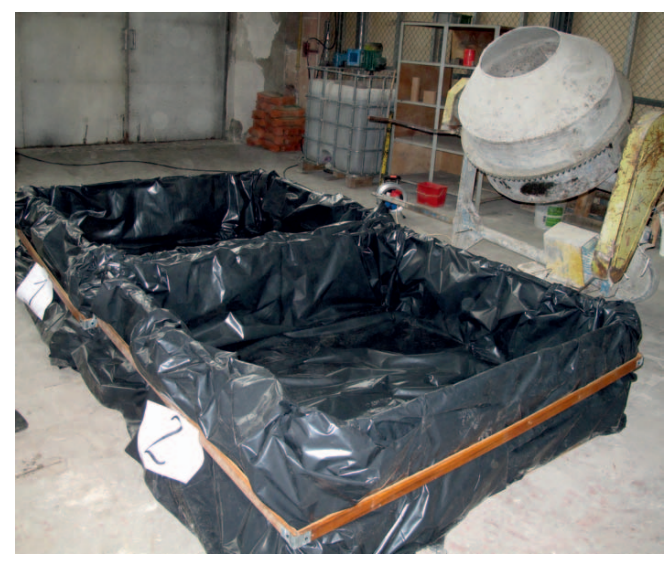

Rys. 6. Stanowisko do przeprowadzania próby zestalania płuczek otworowych
Tablica 1. Właściwości mieszaniny płuczek otworowych wybranych do zestalenia

\begin{tabular}{|l|c|}
\hline \multicolumn{1}{|c|}{ Oznaczenia } & Wartości parametrów \\
\hline Temperatura płuczki $\left[{ }^{\circ} \mathrm{C}\right]$ & 19 \\
\hline Lepkość plastyczna, $\mathrm{PV}[\mathrm{m} \cdot \mathrm{Pas}]$ & 23 \\
\hline Lepkość pozorna, $\mathrm{AV}[\mathrm{m} \cdot \mathrm{Pas}]$ & 32,5 \\
\hline Granica płynięcia, YP $\left[\mathrm{lb} / 100 \mathrm{ft}^{2} / \mathrm{Pa}\right]$ & $19 / 9,1$ \\
\hline Wytrzymałość strukturalna, I/II $[\mathrm{Pa}]$ & $1,7 / 2,2$ \\
\hline Gęstość $\left[\mathrm{kg} / \mathrm{m}^{3}\right]$ & 1360 \\
\hline Filtracja, API $\left[\mathrm{cm}^{3} / 30 \mathrm{~min}\right]$ & 7,6 \\
\hline $\mathrm{pH}$ & 7,6 \\
\hline
\end{tabular}

Na podstawie uzyskanych wyników badań, tj. wytrzymałości na ściskanie otrzymanego półproduktu, która po 14 dniach wynosiła 3,1 MPa, do przeprowadzenia próby półprzemysłowej wytypowano kompozycję na osnowie 35\% cementu CEM I 32,5 z dodatkiem 5\% szkła sodowego. Proces mieszania płuczek z wyżej wymienionymi składnikami przeprowadzono w mieszalniku do sporządzania zapraw cementowych (rysunek 7). Do odmierzonej ilości mieszaniny płuczek w czasie jej mieszania sukcesywnie dozowano wytypowane ilości środków wiążących. Proces mieszania prowadzono aż do uzyskania jednorodnej masy mieszaniny, tj. około 30 $\div 40$ min (rysunek 8). Po stwierdzeniu początku gęstnienia mieszaniny otrzymany półprodukt przelewano do przygotowanych zbiorników (rysunek 7), a po około 10 min ulegał on silnemu gęstnieniu. W trakcie prowadzonego zabiegu pobrane zostały próbki celem oznaczenia czasu wiązania, wytrzymałości na ściskanie

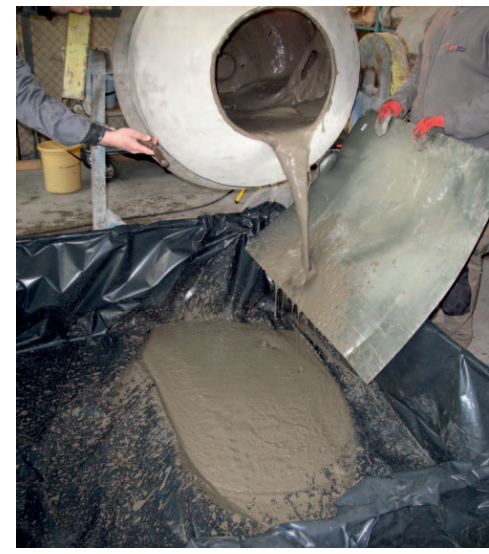

Rys. 7. Mieszanina przygotowana do zestalenia

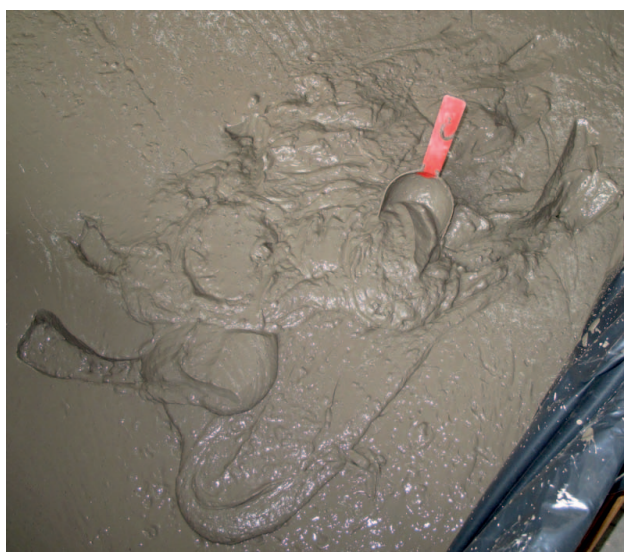

Rys. 8. Zagęszczona mieszanina po 7 i 14 dniach, wymywalności substancji niebezpiecznych oraz toksyczności odcieku.

Na podstawie prowadzonych badań stwierdzono, że początek wiązania mieszaniny płuczek nastąpił po około $30 \mathrm{~h}$, koniec wiązania po 80 h (rysunek 10), wartość wytrzymałości na ściskanie otrzymanego półproduktu po 7 dniach wynosiła 0,9 $\mathrm{MPa}$, a po 14 dniach 1,9 $\mathrm{MPa}$.

Badania wymywalności substancji niebezpiecznych w odcieku z półproduktu wykazały następujące wartości oznaczeń:

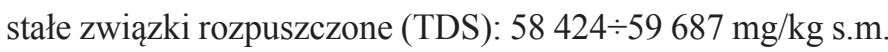
(suchej masy), zawartość jonów $\mathrm{Cl}^{-}: 21300 \div 22547 \mathrm{mg} / \mathrm{kg}$ s.m., zawartość siarczanów: 1984 $\div 1896 \mathrm{mg} / \mathrm{kg}$ s.m., zawartość węgla organicznego (DOC): 3200 $\div 3985 \mathrm{mg} / \mathrm{kg}$ s.m., zawartość metali ciężkich: na niskim poziomie. Spośród wykonanych oznaczeń jedynie zawartość węgla organicznego (DOC) przekroczyła dopuszczalne normy, co mogło być spowodowane obecnością polimerów organicznych zawartych w składach zestalonych płuczek oraz zanieczyszczających je substancji ropopochodnych. 


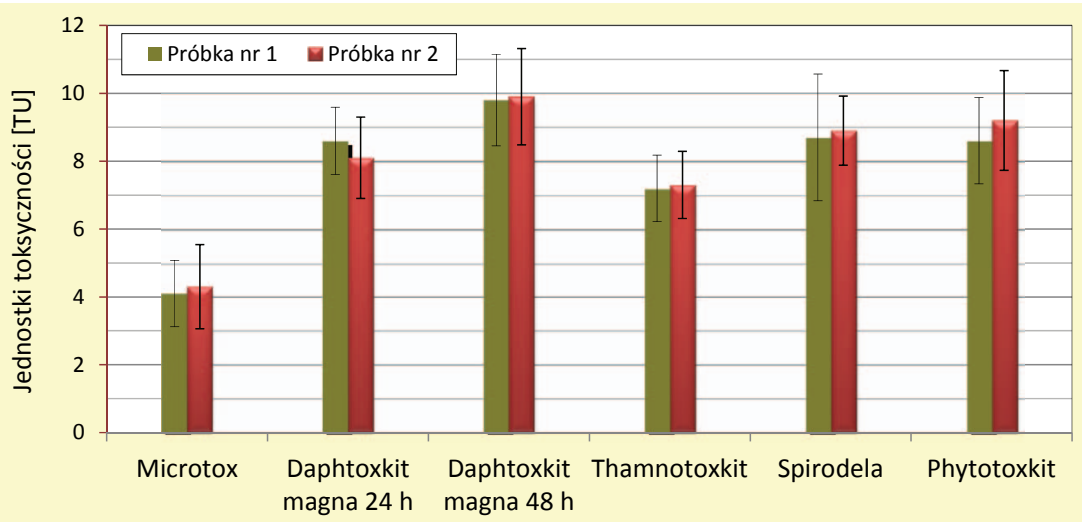

Rys. 9. Wyniki badań toksyczności odcieków z półproduktów uzyskanych po zestaleniu mieszaniny płuczek - próba półprzemysłowa z wykorzystaniem wytypowanych testów toksykologicznych
Wykonane badania toksykologiczne odcieku z półproduktu z wykorzystaniem wytypowanych testów toksykologicznych [1-5, 7] wykazały, że toksyczność wyrażona w jednostkach toksyczności (TU) wynosiła: Microtox: 4,1 $\div 4,3$; Daphtoxkit (48 h): 9,8 $\div 9,9$; Spirodela: $8,7 \div 8,9$; Thamnotoxkit:
7,2 $\div 7,3$; Phytotoxkit: 8,6 $\div 9,2$ (rysunek 9). Odciek z półproduktu można zaliczyć do niskotoksycznych (II klasa toksyczności, TU < 10).

Otrzymany półprodukt został wykorzystany jako materiał posadzkowy podczas układania kostki brukowej (rysunek 10).
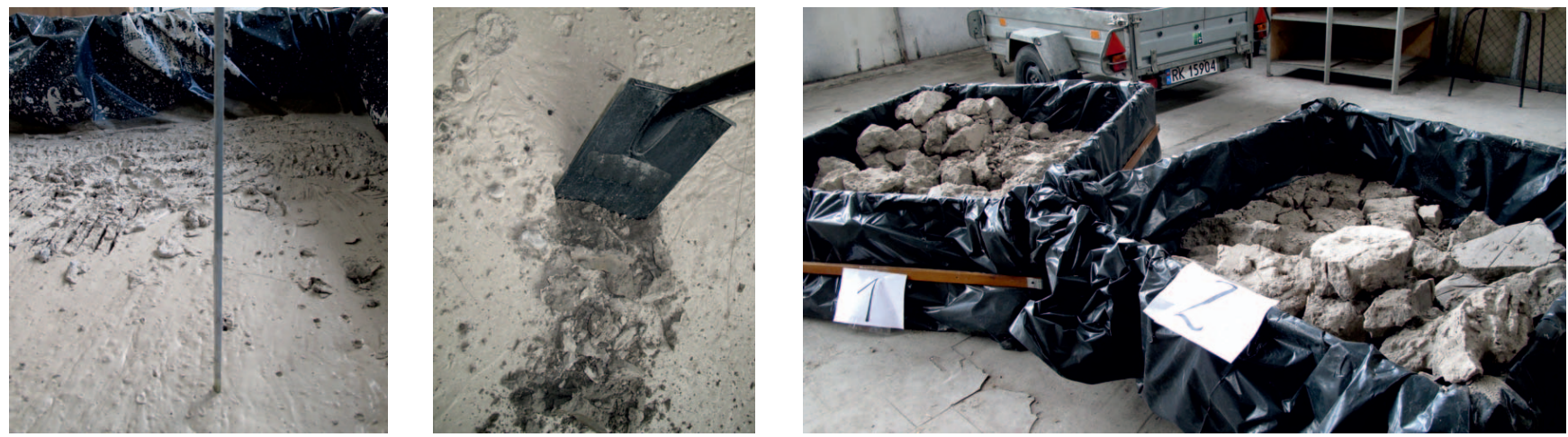

Rys. 10. Otrzymany półprodukt przygotowany do zagospodarowania

\section{Podsumowanie}

Przeprowadzone badania laboratoryjne, jak i próba półprzemysłowa wykazały, że do zestalania odpadowych płuczek wiertniczych może być stosowana kompozycja środka zawierająca materiał wiążący Silment CQ-25 lub cement portlandzki CEM I 32,5 oraz aktywator wiązania - szkło wodne sodowe. Ilości tych środków należy ustalać w testach poprzedzających zestalanie płuczki o określonych parametrach technologicznych w warunkach przemysłowych. Proces zestalania zużytych płuczek wiertniczych może stanowić jeden ze sposobów zagospodarowywania odpadów płynnych otrzymywanych w znacznych ilościach w czasie prowadzonych prac wiertniczych.

Opracowaną kompozycję środka do zestalania zużytych płuczek wiertniczych należy uznać za skuteczną, ponieważ pozwala ona na wiązanie w całości różnych płuczek odpadowych, zarówno stanowiących fazę płynną, jak i stałą. Odpowiedni dobór rodzaju i optymalnych ilości materiałów wiążących w kompozycji ze szkłem wodnym oraz sposób ich dozowania (według opracowanej technologii) skutkuje otrzymywaniem półproduktu charakteryzującego się niską szkodliwością dla środowiska, o czym świadczą wyniki badań wymywalności substancji szkodliwych oraz testy toksykologiczne, a uzyskane parametry wytrzymałościowe (w czasie $7 \div 14$ dni) predestynują go do wykorzystania w celach użytkowych, np. do rekultywacji wyrobisk powierzchniowych i wypełniania wyrobisk podziemnych. Przedstawioną technologię zestalania zużytych płuczek należy zaliczyć do najnowszych metod zagospodarowywania odpadów wiertniczych. 
Artykuł został opracowany na podstawie referatu wygłoszonego na Międzynarodowej Konferencji Naukowo-Technicznej GEOPETROL 2018 pt.: Rozwój technik poszukiwania i eksploatacji złóż węglowodorów. Zakopane-Kościelisko, 17-20.09.2018 r.

\section{Literatura}

[1] Bakopoulou S., Emmanouil C., Kungolos A.: Assessment of Wastewater Effluent Quality in Thessaly Region, Greece, for Determining its Irrigation Reuse Potential. Ecotoxicology and Environmental Safety 2011, vol. 74, nr 2, s. 188-194.

[2] Baudo R., Foudoulakis M., Arapis G., Perdaen K., Lanneau W., Paxinou A.-C.M., Kouvdou S., Persoone G.: History and sensitivity comparison of the Spirodela polyrhiza microbiotest and Lemna toxicity tests. Knowledge and Management of Aquatic Ecosystems 2015, vol. 416, s. 21-28.

[3] Foucault Y., Durand M.J., Tack K., Schreck E., Geret F., Leveque T., Pradère P., Goix S., Dumat C.: Use of ecotoxicity test and ecoscores to improve the management of polluted soils: case of a secondary lead smelter plant. Journal of Hazardous Materials 2013, vol. 246-247, s. 291-299.

[4] Gatidou G., Stasinakis A.S., Iatrou E.I.: Assessing single and joint toxicity of three phenylurea herbicides using Lemna minor and Vibrio fischeri bioassays. Chemosphere 2015, vol. 119, s. S69-S74.

[5] Gondek K., Baran A., Kopeć M.: The effect of low - temperature transformation of mixtures of sewage sludge and plant materials on Content, leachability and toxicity heavy metals. Chemosphere 2014, vol. 117, s. 33-39.

[6] Leonard S.A., Stegemann J.A.: Stabilization/solidification petroleum drill cuttings: leaching studies. Journal of Hazardous Materials 2010, vol. 174, nr 1-3, s. 885-889.

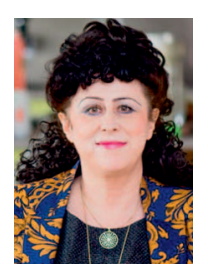

Prof. nzw. dr hab. inż. Teresa STELIGA

Kierownik Zakładu Technologii Eksploatacji

Płynów Złożowych

Instytut Nafty i Gazu - Państwowy Instytut Badawczy

ul. Lubicz 25 A

31-503 Kraków

E-mail: teresa.steliga@inig.pl

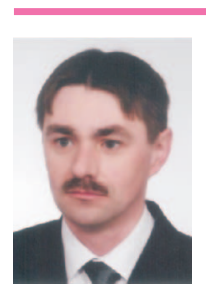

Mgr Piotr JAKUBOWICZ

Starszy specjalista badawczo-techniczny w Zakładzie Technologii Eksploatacji Płynów Złożowych Instytut Nafty i Gazu - Państwowy Instytut Badawczy ul. Lubicz $25 \mathrm{~A}$

31-503 Kraków

E-mail: piotr.jakubowicz@inig.pl
[7] Steliga T., Uliasz M.: Innowacyjna technologia zestalania zużytych pluczek wiertniczych. Prace Naukowe Instytutu Nafty i Gazu - PIB 2018, nr 221, DOI: 10.18668/PN2018.221.

[8] Steliga T., Uliasz M.: Spent drilling muds management and natural environment protection. Mineral Resources Management 2014, vol. 30, nr 2, s. 135-156.

[9] Steliga T., Uliasz M.: Wybrane zagadnienia środowiskowe podczas poszukiwania, udostęniania i eksploatacji gazu ziemnego z formacji łupkowych. Nafta-Gaz 2012, nr 5, s. 273-283.

[10] Steliga T., Uliasz M., Kotwica Ł., Kremieniewski M.: Assessment of mechanical parameters and physical and chemical properties of solidified drilling-related waste. Mineral Resources Management 2018, vol. 34, nr 1, s. 97-118.

[11] Uliasz M.: Wpływ polimerów z I-rzędowymi grupami aminowymi na właściwości inhibitacyjne pluczki wiertniczej. Nafta-Gaz 2011, nr 1, s. 19-29.

[12] Uliasz M., Steliga T.: Technologia zestalania zużytych płuczek wiertniczych. Przegląd Górniczy 2013, t. 69, nr 4, s. 145-154.

[13] Yu-Cheng L., Mian W., Ming-Yan C.: Research progress and prospection on technology of solidification of waste drilling mud treatment. Environmental Science \& Technology 2010, vol. 33, s. 534-537.

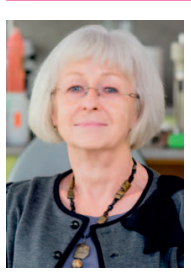

Dr inż. Małgorzata ULIASZ

Kierownik Zakładu Technologii Wiercenia

Instytut Nafty i Gazu - Państwowy Instytut Badawczy ul. Lubicz $25 \mathrm{~A}$

31-503 Kraków

E-mail: malgorzata.uliasz@inig.pl

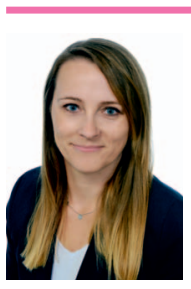

Inż. Anna SZAJNA

Specjalista inżynieryjno-techniczny w Zakładzie

Technologii Wiercenia

Instytut Nafty i Gazu - Państwowy Instytut Badawczy

ul. Lubicz $25 \mathrm{~A}$

31-503 Kraków

E-mail:anna.szajna@inig.pl 